\title{
Is Indian Development Cooperation Taking a New Direction Under Modi?
}

\begin{abstract}
Rising powers such as the BRICS (Brazil, Russia, India, China and South Africa) are taking independent stands and changing the discourse on development cooperation in international fora. India has played a key role in driving this, most recently contributing to the establishment of the BRICS Development Bank and being nominated to host its first presidency. At home, a new Development Partnership Administration signals a commitment to a more coherent and consistent implementation of development cooperation. However, the recently elected Bharatiya Janata Party (BJP)-led coalition government has yet to articulate a clear development policy despite election pledges to strengthen India's position as world leader, and Prime Minister Narendra Modi's proactive foreign policy engagement. India needs to move on from the rhetoric of SouthSouth Cooperation and ad hoc decisions based on high-level bilateral visits, to a more concrete development agenda. It can play to the strength of its civil society experience in poverty reduction, livelihood promotion and good governance, and it needs to develop appropriate regulatory mechanisms for companies operating its lines of credit (LOCs) or involved in foreign direct investment.
\end{abstract}

The legacy of Indian

development cooperation

India's approach to development cooperation changed substantially in the early 1990s, along with major changes in its economic and foreign policy, which moved increasingly towards a capitalist and open market approach. The decision to promote India's strategic economic interests abroad through a dedicated development assistance programme was first taken in 2003 by the BJP-led coalition government of the National Democratic Alliance. The new development assistance strategy had ambitions around:

- providing relief to a select number of bilateral partners using small assistance packages

- considering debt relief for those heavily indebted poor countries (HIPCs) with substantial overdue payments

- launching an 'India Development Initiative' to provide grants or project assistance to developing countries in Africa, South Asia and other parts of the developing world.

However, little progress was made in the following years with the Congress-led UPA government focusing on other policy priorities. In 2007-08, the same Congress-led government proposed the creation of a new agency, the India International Development Cooperation Agency; however, the agency was never established due to the lack of agreement between the Ministry of External

Affairs and the Ministry of Finance on its ministerial affiliation. Finally, in 2012, the government established the Development Partnership Administration (DPA). However, in the three years since, there is still no clear policy paper on international development cooperation (IDC). Instead, both the previous and current governments have tended to draw on and refer to the broad principles of South-South Cooperation,
"India has played a key role in driving the change in discourse on development cooperation." 
without explicitly articulating actionable policy proposals or recommendations around the operationalisation of IDC.

\section{New directions for India's development cooperation?}

\section{Situating India's normative stance}

Under the recently formed BJP government, IDC is instrumental to India's foreign policy agenda and national economic interests. At the same time, the government recognises the importance of articulating a more normative position in line with that of India's first prime minister, Jawaharlal Nehru, who believed that the economic development of all countries is an obligation of the entire international community. Indeed, India has taken a lead in conceptualising the idea of a global South.

In his inaugural address to the United Nations General Assembly, Prime Minister Narendra Modi stated: 'India is part of the developing world, but we are prepared to share our modest resources with those countries that need this assistance as much as we do'. The normative and the pragmatic thus infuse the official discourse on IDC in equal measure, although it is not entirely surprising that the more idealistic articulations of IDC are reserved for the international community, whereas the more pragmatic interpretations of IDC that link assistance to economic and geopolitical reciprocity, are reserved for strategic decision-making at the bilateral level.

\section{Strengthening regional links}

Since Modi's appointment, two major development assistance packages have been announced for countries in South Asia. Modi's first official overseas trip as prime minister was to Bhutan, a country which also happens to be India's largest recipient of development assistance. The Indian and Bhutanese governments entered into an agreement to develop joint venture hydropower projects through the public sector enterprises.

In August 2014, the Export-Import Bank of India (Exim Bank), at the behest of the Indian government, extended a line of credit (LOC) of US\$1bn to the Government of Nepal to finance hydropower, irrigation and infrastructural development projects. The announcement coincided with Modi's visit to Nepal, crucially marking the first such visit made by an Indian prime minister in 17 years. In fact, over 80 per cent of India's grant and loan commitments have been made to Afghanistan, Bangladesh, Bhutan, the Maldives, Nepal and Sri Lanka. Clearly, cementing strong strategic ties with neighbouring countries is a priority for this government.

\section{Ensuring mutual gains}

While Indian development cooperation has always historically been linked to foreign policy objectives, it is increasingly being linked directly to India's own national development.

Following on from India's commitments to Bhutan in 2014, an Indian official was quoted as saying, 'Our hydropower cooperation with Bhutan is a classic example of win-win cooperation. The hydropower projects generate export revenues for Bhutan, cement our economic partnership and provide clean and low-cost electricity to India'. The win-win principle is an established tenet of South-South Cooperation which emphasises the elements of partnership, mutual gain and reciprocity between partners involved in development cooperation transactions. Demonstrating its alignment with the principles of South-South Cooperation is a deliberate attempt by the Indian Government to distinguish its approach from that of traditional, Western, Organisation for Economic Co-operation and DevelopmentDevelopment Assistance Committee (OECD-DAC) donors. As Modi, in an address to the Nepali Parliament, put it, 'We will double the electricity we are giving you today. In ten years, you will be helping us'.

\section{India's relationship with Africa (and rivalry with China)}

Commercial engagement with Africa has been on the rise, in part due to the opportunities it provides for India to build its energy security. Under the new government, an LOC worth US\$500m was issued to Mauritius for financing of its petroleum storage and bunkering facilities. Modi is expected to reveal his government's Africa policy at the next India-Africa Summit later this year. The summit will be significant in that, unlike previous years, the Indian Government will invite all 54 African heads of state to New Delhi. This may be an attempt to counter the Chinese influence on the African continent and an indication of India's desire

"While Indian
development
cooperation
has always
historically
been linked to
foreign policy
objectives,
it is now
increasingly
linked directly
to India's
own national
development."


to increase cooperation between African states as part of its wider foreign and foreign economic policy goals.

\section{The growing role of the Indian private sector}

The nature of the projects being supported by the new government is indicative of its overarching thinking and macro-level approach towards development. India under Modi wishes to project itself as a power that is friendly to the concept of 'development as growth' and 'development as business partnership' and to extend this idea to the global South. While there are, of course, instances of support for social infrastructure and community-based projects, these pale in comparison to the scale of assistance being given for infrastructure-oriented projects. Under the 'development as growth' model, the Indian private sector plays a hugely important role.

In order to leverage larger funds beyond the Ministry of External Affairs' budget, Modi has introduced joint venture partnerships between Indian public sector units (PSUs) and PSUs in partner countries. For example, as part of the government's hydropower agreement with Bhutan, three Indian public sector hydropower companies - National Hydroelectric Power Corporation (NHPC), Satluj Jal Vidyut Nigam (SJVN) and Tehri Hydro Development Corporation (THDC) - are collaborating on four joint venture hydroelectric projects. Modi's use of the expression B2B - Bharat to Bhutan - to describe bilateral relations between the two countries also astutely captures the increasingly 'business-to-business' component of this partnership.

\section{Championing the establishment of Southern-led development finance institutions}

Although Indian development cooperation typically refers to bilateral development assistance, India's growing role in supporting and providing leadership to Southern-led multilateral development cooperation initiatives is notable. In the past year alone, India has signed up to three major multilateral institutions: the BRICS Development Bank (New Development Bank), the Asia Infrastructure Investment Bank and the South Asian Association for Regional Cooperation
(SARRC) Development Bank. All three institutions are being led by emerging economies from the South.

At the BRICS Summit in Brazil in July 2014, the New Development Bank whose primary objective is to fund infrastructure and sustainable development projects was signed into existence. India was nominated to host its first presidency. The bank is significant in that it has the potential to change the terms of aid. Firstly, for smaller developing countries, it offers the possibility of accessing credit without the economic and political conditionalities of privatisation and liberalisation that are linked to the Bretton Woods institutions. Secondly, no single BRICS country would be authorised to increase its share of capital without the agreement of the other four countries, a requirement allegedly put forward by India to ensure that no single country dominates the bank.

In October 2014, 21 Asian nations including China and India signed an agreement to establish a new infrastructure investment bank which will provide rich resource capital base for infrastructure financing, and reduce the dependency on other established multilateral development banks such as the Asian Development Bank, the World Bank or the International Monetary Fund. More recently, at the SAARC Summit in November 2014, member countries agreed in principle to establish a SAARC Development Bank. Officials state that India would be the 'natural choice' for setting up the bank, as it is arguably the largest and most powerful economy in the region.

\section{Domestic debate}

Recent developments around IDC have received little attention in the media. Civil society organisations (CSOs), while much more aware of the key issues compared to a year ago, still lag in leading the debate on IDC and their own role in development overseas. Although most broadly support development cooperation overseas, they also have widely divergent views around engaging with IDC. For instance, whilst some are keen to be engaged in development projects overseas in collaboration with the Indian Government, others prefer to initiate discussions around creating a framework for accountability and transparency. Select thinktanks such as Research Information Systems, Centre for Policy Research, and
"Indian development cooperation typically refers to bilateral assistance, however its role in supporting and providing leadership to Southern-led multilateral development cooperation is growing." 
the recently set up Forum for Indian Development Cooperation convene meetings attended by intellectuals, policymakers and CSOs, to track and discuss development cooperation issues.

Overall, the private sector has welcomed the opportunities offered by the new, pro-business framing of IDC. However, the few enforceable regulatory mechanisms to monitor the activities of Indian companies operating overseas (whether state-owned or private) have been a particular source of concern for civil society. With regard to the LOCs, there are often delays and slippages in timelines on the part of Indian companies contracted for projects under this programme. At the same time, the activities of Indian multinational companies operating overseas require much greater scrutiny, particularly in relation to their contribution to the reduction of poverty and the creation of livelihoods in the countries in which they operate.

\section{Policy recommendations}

- In policy terms, India needs to plan a development agenda, which is not so much based on ad hoc decisions linked to bilateral high-level visits, but rather is part of an integrated plan that yields results. The government should clearly articulate its policy on development cooperation, preferably through a consultative process. It also needs to establish robust monitoring and evaluation systems to capture the impacts and results of IDC.

- For business, the government should develop clear rules and regulatory mechanisms to govern the operation of business overseas - both for companies operating under the LOC scheme and companies involved in foreign direct investment. In addition, a transparent procurement process should be established for companies contracted under the LOC scheme. The government's role should be to evaluate and monitor these companies' compliance with these guidelines.

- The government needs to expand its current economic growth-centred approach to development cooperation in order to integrate support to good governance initiatives in partner countries. It is critical that civil society initiatives and ideas about poverty reduction, livelihood promotion and good governance, are welcomed.

- India's participation in all three Southern-led multilateral banks signals a strong commitment to leveraging additional finances to meet its own infrastructural requirements as well as contributing to the development of a more Southern country-led international development cooperation architecture. However, to date, there has been no dialogue on the social and environmental safeguards policies of these institutions. To ensure that these banks are effective alternatives to Western-dominated multilateral institutions of finance, it would be critical to ensure that such policies are enacted and enforced, and that accountability mechanisms are similarly in place.

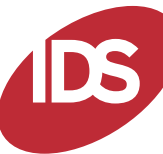

IDS Policy Briefings are published by the Institute of Development Studies and aim to provide high quality analysis and practical recommendations for policymakers on important development issues. To subscribe: www.ids.ac.uk/idspolicybriefings

Institute of Development Studies, Brighton BN1 9RE UK

T+44 (0) 1273606261 F + 44 (0) 1273621202 E ids@ids.ac.uk W www.ids.ac.uk

v twitter.com/IDS_UK \#idspolicy $\mathbf{f}$ facebook.com/idsuk

\section{Further reading}

Chaturvedi, S.; Chenoy, A.

Chopra, D.; Joshi, A. and

Lagdhyan, K.H. (2014) Indian

Development Cooperation: the

State of the Debate, IDS Evidence

Report 95, Brighton: IDS

Maudsley, E. (2014) 'Public

Perceptions of India's Role as a

Development Cooperation

Partner: Domestic Responses to

Rising "Donor" Visibility', Third

World Quarterly 35.6: 958-79

Naidu, S. and Rwigi, E. (2013)

'India's Africa Trade Policy under

the Modi Government: Business

as Usual or the Makings of a

Strategic Reorientation?'

Bridges Africa 4.2, www.ictsd.

org/bridges-news/bridges-

africa/news/india\%E2\%80\%99s-

africa-trade-policy-under-the-

modi-government-business-as

(accessed 2 June 2015)

\section{Credits}

This IDS Policy Briefing was

written by independent

researcher Supriya Roychoudhury

in collaboration with Anuradha

Chenoy, Professor, School of

International Studies, Jawaharlal

Nehru University, Delhi and

Deepta Chopra and Anuradha

Joshi, IDS Research Fellows.

It was edited by Emilie Wilson,

and was produced as part of the

Rising Powers in International

Development programme,

supported with UK aid from

the UK Department for

International Development.

The opinions expressed are

those of the author and do not

necessarily reflect the views of

IDS or the UK government's

official policies.

Readers are encouraged to

quote and reproduce material

from issues of IDS Policy Briefings

in their own publication. IDS

requests due acknowledgement

and quotes to be referenced as

above.

AG Level 2 Output ID: 588

(c) Institute of Development Studies, 2015 ISSN 1479-974X 